\title{
Action of ear acupuncture in people with chronic pain in the spinal column: a randomized clinical trial ${ }^{1}$
}

\author{
Caroline de Castro Moura² \\ Denise Hollanda lunes ${ }^{3}$ \\ Silvia Graciela Ruginsk ${ }^{4}$ \\ Valéria Helena Salgado Souza ${ }^{5}$ \\ Bianca Bacelar de Assis $^{6}$ \\ Erika de Cássia Lopes Chaves $^{7}$
}

\begin{abstract}
Objectives: to assess the action of ear acupuncture on disability and tissue temperature in people with chronic pain in the spinal column. Method: a clinical trial with a sample of 110 people, randomized into three groups: Treatment, Placebo and Control. The assessment instruments were the Rolland Morris Disability Questionnaire (RMDQ) and a thermographic camera, administered before the first treatment session, one week after and 15 days after (follow-up) the fifth session of ear acupuncture. In the analysis of the data, the Kruskal Wallis, Student-Newman Keuls and Wilcoxon tests were applied. Results: there was a significant reduction in disability in the Treatment and Placebo groups between the initial and final assessments $(p<0.05)$ and between the initial assessments and follow-up $(p<0.05)$. In the final assessment, the Treatment group presented improvement of disability when compared with the Placebo and Control groups $(p<0.05)$. There was an increase in mean tissue temperature of the dorsal region between the initial and follow-up assessments in Treatment and Control groups $(p<0.05)$, and between the final assessments and follow-up in the Treatment and Placebo groups $(p<0.05)$. Conclusion: ear acupuncture was efficacious in reducing disability and increasing tissue temperature in people with chronic pain in the spinal column. Brazilian Register of Clinical Trials (RBR-5X69X2).
\end{abstract}

Descriptors: Chronic Pain; Back Pain; Acupuncture, Ear; Rehabilitation; Complementary Therapies; Nursing.

\footnotetext{
Paper extracted from master's thesis "Ação da acupuntura auricular chinesa sobre a dor Crônica em pessoas com distúrbios musculoesqueléticos na coluna vertebral: ensaio clínico randomizado", presented to Universidade Federal de Alfenas, Alfenas, MG, Brazil. Supported by Coordenação de Aperfeiçoamento de Pessoal de Nível Superior (CAPES), Process \#1503540, Brazil.

2 Doctoral student, Universidade Federal de Minas Gerais, Belo Horizonte, MG, Brazil.

3 PhD, Associate Professor, Departamento de Fisioterapia, Universidade Federal de Alfenas, Alfenas, MG, Brazil.

${ }^{4} \mathrm{PhD}$, Adjunct Professor, Departamento de Ciências Fisiológicas, Universidade Federal de Alfenas, Alfenas, MG, Brazil.

5 MSc, Professor, Departamento de Enfermagem, Faculdade de Ciências e Tecnologias de Campos Gerais, Campos Gerais, MG, Brazil.

${ }^{6}$ Master's student, Universidade Federal de Alfenas, Alfenas, MG, Brazil.

7 PhD, Adjunct Professor, Escola de Enfermagem, Universidade Federal de Alfenas, Alfenas, MG, Brazil.
}

\section{How to cite this article}

Moura CC, Iunes DH, Ruginsk SG, Souza VHS, Assis BB, Chaves ECL. Action of ear acupuncture in people with chronic pain in the spinal column: a randomized clinical trial. Rev. Latino-Am. Enfermagem. 2018;26:e3050. [Access ]; Available in: i . DOI: http://dx.doi.org/10.1590/1518-8345.2678.3050. 


\section{Introduction}

Pain is characterized as the organism's response to aggression or any pathological disturbance. When it becomes chronic, it is considered a pathology in itself and is prevalent at a high level throughout the world, principally when it affects the lumbar region ${ }^{(1)}$.

The severity and chronic nature of back pain are associated with severe functional limitations(2). In people with disorders of the musculoskeletal system, particularly in the lower limbs and in the lumbar region, impaired physical mobility is one of the most frequent consequences ${ }^{(3)}$, causing serious compromise in these people's daily routine, resulting in a high degree of dependency ${ }^{(3-4)}$.

Assessing chronic pain and its consequences, as well as its treatment, is a major challenge; as this is a subjective phenomena, it is important to invest in studies which can investigate not only the intensity of the pain, but also its implications in people's lives.

The Rolland Morris Disability Questionnaire (RMDQ) $^{(5)}$ is one of the most-used instruments for assessing inability to undertake activities of daily living among people with chronic pain in general(6). It allows an appropriate assessment of the treatment and of the progression of the patients with chronic pain, through quantifying the limitations caused by this, in both physical and mental functions ${ }^{(5)}$.

In addition to the behavioral approach, commonly used in investigations of chronic pain, it is necessary to identify the physiological aspects involved in the process of recognizing the painful neuromuscular conditions. In this regard, change in tissue temperature is an important aspect for assessment, as this reflects the kinetic energy of the individual molecules in accordance with simultaneous recruitment of the mechanisms of heat retention and $\operatorname{loss}^{(7)}$.

The skin is an efficient system for controlling heat. The conducting of heat through this organ is controlled by the degree of vasoconstriction of the arterioles, which supply the cutaneous venous plexus with blood. This vasoconstriction is under control of the sympathetic input of the autonomous nervous system, and takes place in response to changes in the central temperatures of the body and of the environment(8). Thus, variations in the skin temperature may reflect internal changes, particularly in the activity of the skeletal muscle.

Another approach indicated for assessing painful conditions, therefore, which extends the resources for measuring the same, is infrared thermography - an imaging test which is of proven safety, noninvasive, painless and which does not require contact with any part of the body ${ }^{(9)}$.
The treatment of chronic pain is complex and long, and leads to dependence on the health services and to high financial costs - apart from changes in the various social, physical and emotional aspects experienced during the same. Accordingly, there is a consensus that it is necessary to invest in integrative and complementary therapies which allow demedicalization and are low $\operatorname{cost}^{(10)}$. All the same, these therapies - described and recommended for use in clinical practice - must be tested through controlled clinical trials.

Among the therapeutic resources currently described as integrative, complementary and holistic, used for the treatment and control of chronic pain, ear acupuncture (EA) has stood out. Based in the precepts of Traditional Chinese Medicine (TCM), this therapy uses a stimulation of auricular points, so as to harmonize the function of the organs and viscera of the human body ${ }^{(11)}$. EA has, therefore, preventive and curative aspects, as well as promoting relief of the signs and symptoms of different conditions.

The scientific evidence centered on the effects of EA on chronic pain in the spinal column, however, is as yet limited due to the small number of studies involving this topic, as well as to the methodological shortcomings indicated in the same ${ }^{(12)}$.

The objective of the present study was, therefore, to assess the action of EA on disability and tissue temperature in people with chronic pain in the spinal column.

\section{Method}

This is a controlled randomized clinical trial ${ }^{(13)}$, of the parallel and blind type, undertaken between June 2015 and March 2016, in a university in Minas Gerais, Brazil. The population was made up of 535 people awaiting treatment in the institution's physiotherapy clinic.

The screening of the sample of volunteers with complaints of pain in the spinal column was undertaken by telephone. As a result, from the initial population, 149 people were excluded as they presented other types of pain.

The following were established as inclusion criteria for selecting the sample: (1) age range between 18 and 80 years old; (2) presence of chronic pain in the spinal column for three months or over(14), of any origin; (3) self-reported intensity of pain $\geq 4$, on a numeric pain scale of 11 points $^{(15)}$; and (4) availability to attend the EA sessions. The exclusion criteria were as follows: (1) individuals with infections, inflammation or injuries in the ear; 2) allergy to metal or to microporous tape; (3) undertaking previous energy therapy in the three months prior to the intervention; (4) receiving physiotherapy; (5) in continuous use of medication for pain relief; (6) refusal to receive the ear treatment through the use of needles and (7) pregnant women. 
The sample calculation was undertaken based on a pretest with 15 people ( 5 per group), using the GPower software, version 3.1, and BioEstat, version 5.0 software. A test power of $90 \%$ was adopted, as was a mean effect size (0.5) and a level of significance of $5 \%$, resulting in the need for 30 individuals per group. So as to avoid sample losses, the calculation was corrected by $20 \%{ }^{(16)}$. The eligible population obtained was of 110 individuals, and 83 concluded the study (Figure 1), with a loss of $27(24.54 \%)$ individuals.

The volunteers were randomly placed in three study arms: Treatment Group $(n=37)$, Placebo Group $(n=36)$ and Control Group $(n=37)$. The randomization was made in four blocks, with approximately 27 people per block, by a researcher from outside the study, using the R software (version 3.1.1). Each number in a random sequence generated was placed in an opaque envelope and handed to the interventionist in the first intervention session.

The assessments were undertaken at three points by the same trained investigators: before the first EA session, one week after the fifth session, and during the 15 day follow-up period.
The sociodemographic and clinical profile was determined by the following variables: age, sex, duration and cause of pain. The Rolland Morris Disability Questionnaire (RMDQ) was used to assess the interference of the pain in the activities of daily living(17).

The RMDQ has 24 items with a total score varying from zero (no disability) to 24 (severe disability) and measures items related to the impact of the pain on the physiological functions (such as walking and movement, sleep and rest, appetite), psychological functions (irritation and bad mood) and social functions (interaction with other people, domestic and work activities) ${ }^{(5)}$. This instrument has been translated, adapted and validated to produce a Brazilian version ${ }^{(17)}$ and has appropriate psychometric properties ${ }^{(6)}$.

In order to assess the tissue temperature of the cervical, thoracic and lumbar regions, images were taken using a thermographic camera (E-60 bx, ESTONIA) with resolution of $320 \times 240$ (76,800 pixels), in the spectral range of long-wave infrared radiation (7-13 $\mu \mathrm{m})$ for dynamic study $(60 \mathrm{~Hz})$, with lenses with resolution of $25^{\circ} \times 19^{\circ}$, positioned horizontally at a distance of $3 \mathrm{~m}$ from the patient and $1 \mathrm{~m}$ vertically from the ground. For this assessment, the room was previously air-conditioned to $20^{\circ} \mathrm{C}$ for 20 minutes $^{(18)}$.

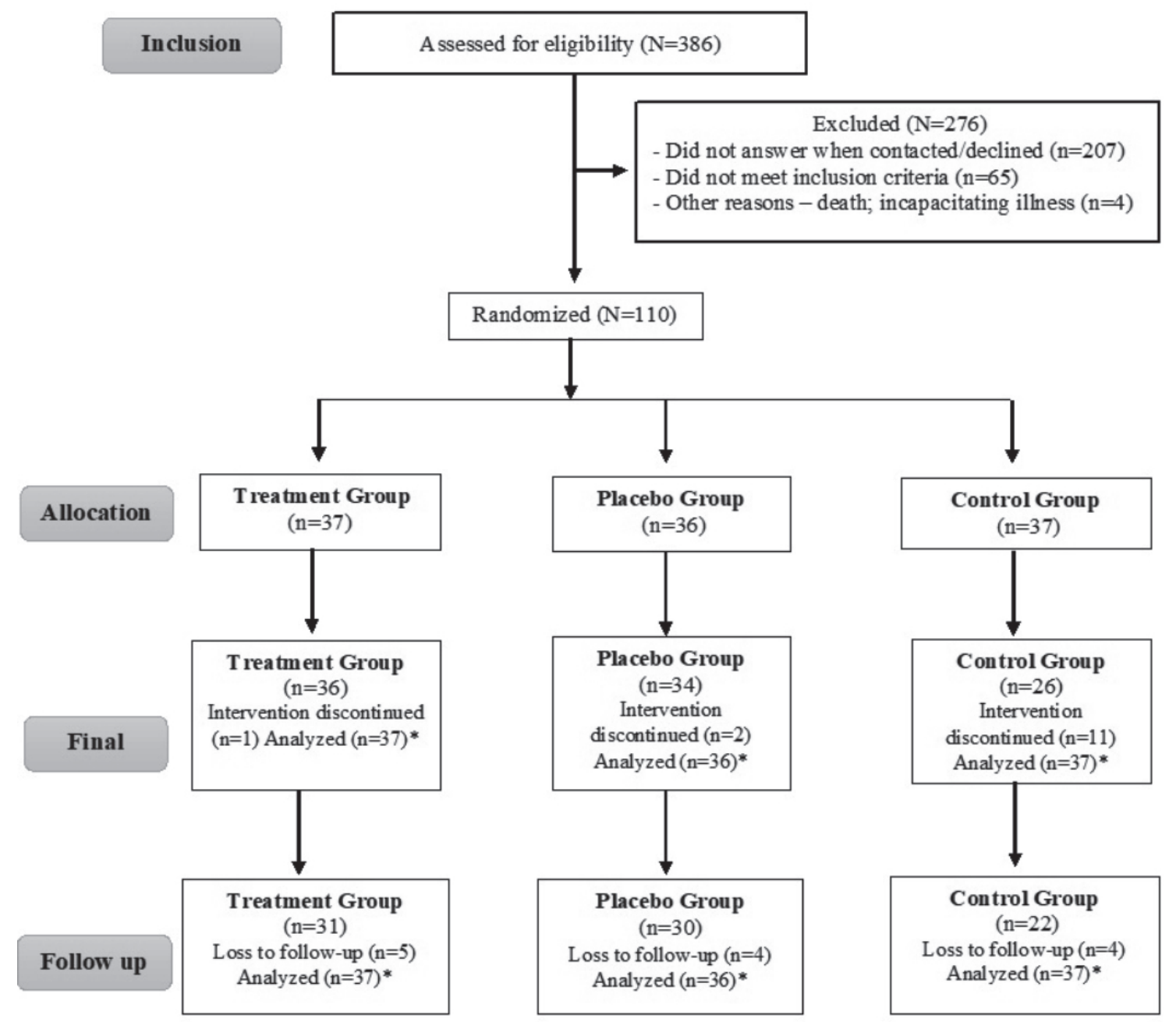

*Analyzed through Intention-to-Treat.

Figure 1 - Flowchart of the participants involved in the study. Alfenas, MG, Brazil, 2016 
In order to take the thermographic photograph ${ }^{(18)}$, the volunteers remained at rest for 15 minutes and for the capturing of the image, remained in an orthostatic position, with the region of their backs uncovered and with the arms crossed in front of the chest. Doublesided polystyrene markers were attached against the following previously standardized points to assist in the assessment of the images ${ }^{(19)}$ : cervical region (mastoid process, bilaterally; at the level of C7, bilaterally); thoracic region (acromion, bilaterally; free extremity of the $12^{\text {th }}$ rib, bilaterally); and lumbar region (free extremity of the $12^{\text {th }}$ rib, bilaterally; iliac spine, bilaterally). The thermographic images were analyzed using the FLIR Tools software, version 5.2.15161.1001.

In order to find the best therapeutic scheme for treatment, a protocol was created for intervention using EA, based in the recommendations of the Standards for Reporting Interventions in Clinical Trials of Acupuncture(20), through which the following were defined: the duration of treatment, the number of sessions, and the devices and application points. This was subjected to an assessment process by five acupuncturists with over 10 years of experience in the area, and was then tested in a pretest.

The EA treatment, in the Treatment and Placebo groups, was undertaken using semipermanent auricular needles, sterilized and disposable, $0.20 \times 1.5$ millimeters in size, of the Complementar Agulhas $\AA$ brand. The ear was thoroughly cleaned beforehand using cotton and ethyl alcohol $70 \%$. Next, the location of the auricular acupuncture points was confirmed using the Acu-Treat localizing device (DongBang $\AA$ ); and the needles were inserted and fixed with beige anti-allergic micropore.

The auricular points for the Treatment Group were distributed according to the energy balance and according to the standards of TCM, and were applied in the following order: Shenmen (TF4); Kidney (CO10); Sympathetic nerve (AH6a); points for reestablishing energy balance, corresponding to one organ and one viscera; Cervical Vertebrae (HA13), Thoracic Vertebrae (AH11) and/or Lumbar Vertebrae (AH9), depending on the location of the pain ${ }^{(21)}$.

In the placebo Group, a single point was applied, termed "Eye" (LO5). This point, sited in the center of the earlobe ${ }^{(21)}$, is far from the points applied in the Treatment group, and is not related to the focus of observation.

Both groups received five sessions of EA, once a week, over a period of one and a half months, alternating the ear in each session. This time was defined based in the experience of the acupuncturists who assessed the treatment scheme proposed, as well as in the results obtained in the pretest. The entire procedure was undertaken by a professional who is specialized in acupuncture, with experience in the area for over three years $^{(20)}$.

The individuals who were allocated to the Control group, during the assessment period, received no guidance and no intervention.

The blinding was applied to the study investigators and to the person who analyzed the results(22); these people did not know to which group each volunteer had been allocated.

The data collected were tabulated using Microsoft Office Excel ${ }^{\circ} 2013$, by two independent researchers, and their consistency was tested. For the statistical analysis, the Statistical Package for the Social Sciences, version 23.0, and BioEstat, version 5.0, were used.

The data were analyzed through Intention-toTreat (ITT), through the repetition of the values of the last assessment. For the sociodemographic and clinical variables, the Chi-squared tests and Kruskal Wallis tests were used. For the interclass assessment, we used the Kruskal Wallis test, followed by the StudentNewman Keuls test when necessary. For the interclass assessment, we used the paired Wilcoxon test. The level of significance adopted was of $5 \%$.

This study was approved by the Research Ethics Committee (CAAE N. 43818115.6.0000.5142/Opinion N. 1.041.266). Before the study began, the participants were assured of their right to receive the treatment at the end of the follow-up period, so as to comply with the ethical precepts and improve adherence. Thus, at the end of the study, the volunteers from the Placebo and Control groups received the same sessions of EA as the Treatment group.

\section{Results}

A total of 110 individuals with chronic pain in the spinal column participated in the study. The comparison between the groups, according to the sociodemographic and clinical variables, indicates homogeneity between them - and, consequently, the adequacy of the randomization process, as shown in Table 1.

On assessing the impact of the auricular intervention on the disability resulting from the pain, through the use of the RMDQ, it was ascertained that statistically significant reductions were obtained for the Treatment and Placebo groups, between the initial and final assessments, and the initial and follow-up assessments. Furthermore, in the interclass analysis, and the final assessment, the Treatment group differed from the others, with a lower level of disability, as shown in Table 2.

There was a statistically significant increase in mean tissue temperature of the dorsal region, obtained through the infrared thermography, in the intraclass analysis (initial and follow-up/final and follow-up), as shown in Table 3. In the interclass analysis, the groups did not differ. 
Table 1 - Characterization of the sample by age, sex, duration and causes of the pain. Alfenas, MG, Brazil, 2016 $(n=110)$

\begin{tabular}{|c|c|c|c|c|c|}
\hline \multirow[b]{2}{*}{ Variables } & & \multicolumn{3}{|c|}{ Groups } & \multirow[b]{2}{*}{ P Value } \\
\hline & & $\begin{array}{c}\text { Treatment } \\
(n=37)\end{array}$ & $\begin{array}{c}\text { Placebo } \\
(n=36)\end{array}$ & $\begin{array}{c}\text { Control } \\
(n=37)\end{array}$ & \\
\hline Age $\left(x^{*} \pm s d^{\dagger}\right)$ & (years) & $47.5 \pm 13.9$ & $51.0 \pm 14.9$ & $46.2 \pm 15.7$ & $0.272^{\ddagger}$ \\
\hline \multirow{2}{*}{$\operatorname{Sex}\left(\%^{\S}\right)$} & Male & 18.9 & 25.0 & 18.9 & \multirow{2}{*}{$0.763^{\|}$} \\
\hline & Female & 81.1 & 75.0 & 81.1 & \\
\hline Duration of pain $\left(\mathrm{x}^{*} \pm s \mathrm{~d}^{\dagger}\right)$ & (months) & $47.5 \pm 13.9$ & $51.0 \pm 14.9$ & $46.2 \pm 15.7$ & $0.850^{\ddagger}$ \\
\hline \multirow{2}{*}{ Causes of the pain $\left(\%^{\S}\right)$} & Postural changes & 16.2 & 44.4 & 16.2 & \multirow{2}{*}{$0.057 \|$} \\
\hline & Osteoarthritis & 35.1 & 41.6 & 16.2 & \\
\hline
\end{tabular}

*Mean; + Standard deviation; łKruskal-Wallis test; §Percentage; IIChi-squared test.

Table 2 - Intraclass and interclass analyses of disability, expressed in median, (mean \pm standard deviation) and confidence interval at $95 \%$, in the three groups and at three points. Alfenas, MG, Brazil, $2016(n=110)$

\begin{tabular}{lccc}
\hline \multirow{2}{*}{ Groups } & \multicolumn{3}{c}{ Assessments } \\
\cline { 2 - 4 } & Initial & Final & Follow up \\
\hline \multirow{2}{*}{ Treatment } & $12.0^{\star \dagger}$ & $4.0^{*}$ & $6.0^{\dagger}$ \\
$(\mathrm{n}=37)$ & $(11.8 \pm 5.8)$ & $(6.6 \pm 6.3)$ & $(7.5 \pm 6.7)$ \\
& $9.8-13.7$ & $4.4-8.8$ & $5.3-9.7$ \\
Placebo & $12.5^{\star+}$ & $8.0^{*}$ & $9.5^{\dagger}$ \\
$(\mathrm{n}=36)$ & $(12.8 \pm 7.0)$ & $(9.9 \pm 7.2)$ & $(10.1 \pm 7.7)$ \\
& $10.4-15.2$ & $7.5-12.4$ & $7.4-12.7$ \\
Control & 11.0 & 11.0 & 11.0 \\
$(\mathrm{n}=37)$ & $(10.2 \pm 5.5)$ & $(11.1 \pm 6.2)$ & $(10.2 \pm 6.9)$ \\
& $8.4-12.1$ & $9.0-13.1$ & $8.6-13.2$ \\
\hline
\end{tabular}

$*_{p}<0.05$ between initial and final assessments (Wilcoxon); $+p<0.05$ between initial and follow-up assessments (Wilcoxon); $\neq p<0.05$ interclass analysis (Kruskal-Wallis, followed by Student-Newman Keuls).

Table 3 - Intraclass and interclass analyses of the mean tissue temperature of the dorsal region, expressed in median, (mean \pm standard deviation) and confidence interval at $95 \%$, in the three groups and at three points. Alfenas, MG, Brazil, 2016. $(n=110)$

\begin{tabular}{lccc}
\hline \multirow{2}{*}{ Groups } & \multicolumn{3}{c}{ Assessments } \\
\cline { 2 - 4 } & Initial & Final & Follow up \\
\hline \multirow{2}{*}{ Treatment } & $30.4^{*}$ & $30.2 \dagger$ & $30.9^{*} \dagger$ \\
$(\mathrm{n}=37)$ & $(30.5 \pm 0.7)$ & $(30.1 \pm 1.3)$ & $(30.8 \pm 0.3)$ \\
& $30.2-30.7$ & $29.6-30.5$ & $30.5-31.1$ \\
Placebo & 30.4 & $30.2 \dagger$ & $30.8 \dagger$ \\
$(\mathrm{n}=36)$ & $(30.4 \pm 0.9)$ & $(30.1 \pm 1.2)$ & $(30.6 \pm 0.8)$ \\
& $30.1-30.7$ & $29.7-30.5$ & $30.3-30.9$ \\
Control & $30.3^{*}$ & 30.3 & $30.7^{*}$ \\
$(\mathrm{n}=37)$ & $(30.1 \pm 1.0)$ & $(30.2 \pm 1.3)$ & $(30.5 \pm 1.3)$ \\
& $29.8-30.5$ & $29.7-30.6$ & $30.1-30.9$ \\
\hline
\end{tabular}

$* p<0.05$ between initial and follow-up assessments (Wilcoxon) $;+p<0.05$ between final and follow-up assessments (Wilcoxon).

\section{Discussion}

Chronic pain in the spinal column is incapacitating, principally when in the lumbar region(23). Studies ${ }^{(19,24)}$ have demonstrated that the level of disability varies proportionally to the intensity and to the pain threshold, and causes limitations in daily activities (such as difficulties in dressing, sitting, standing up, walking and lifting objects), changes in sleep and constant worry, as well as absenteeism from work ${ }^{(25)}$.
It is, therefore, necessary to identify interventions capable of reducing the disability of people with chronic pain in the spinal column. In this context, the present study corroborates that ear acupuncture is efficient in minimizing this disability.

One clinical improvement in disability caused by pain processes is obtained if the RMDQ score reduces from the baseline by $30 \%$ and the pain in the spinal column is classified as better on a global evaluation scale(26). This study's volunteers who received the EA protocol for chronic pain in the spinal column experienced a reduction of $66.66 \%$ in the level of disability in the final assessment, compared with the initial assessment. This effect lasted 15 days, until the point of the follow-up assessment, at which a reduction of $50 \%$ in the levels of disabilities was observed.

Equally, other researchers(27-28) have observed improvement in functional lumbar capacity with treatment undertaken using EA. For Traditional Chinese Medicine, lumbar pain is a syndromic manifestation related to energy changes of organs such as the kidneys. As a result, the stimulation of this and of other auricular points indicated as calming and analgesic, such as that undertaken here, is reflected through the whole organism, helping to reestablish the energy balance of the body as a whole(29).

In the placebo group, the reduction in disability was below that of the volunteers who received the treatment, demonstrating that true EA is significantly more efficacious than the simulated treatment, which corroborates the results of studies(27-28) that have also shown that the score for disability in the RMDQ reduced most in the group that received the true intervention, when compared to the placebo group.

The effects in the placebo group cannot, however, be ignored. These effects can be explained due to the possible psychological effects which may appear due to the volunteers' expectations in relation to the therapy, which is termed the "placebo effect"(30). Indeed, studies have indicated that pain influences many dimensions 
apart from the physical aspects, such as that the psychological factors ${ }^{(31-32)}$.

The protocol used in this study promoted the relief of the chronic pain in the spinal column and, consequently, an improved microcirculatory profile in the area affected, which may be highly desirable for reestablishing the chronic pain conditions. Some authors ${ }^{(33)}$, who have already analyzed the patterns of skin temperature in musculoskeletal disorders, have also found an increase of this in the place affected by the pain, during the treatment of temporomandibular disorder.

The changes of temperature in specific regions of the body can indicate physiological changes ${ }^{(34)}$ and may be used as a parameter in assessing painful conditions. Therefore, infrared thermography is an appropriate method for studies investigating such phenomena, as it provides images of distribution of the temperature of the skin of the body, which is conditioned by the activities of the microcirculation ${ }^{(35)}$.

In cases of chronic injuries, such as - for example - in the myofascial dysfunctions, hypo-radiant areas can be detected in infrared images. This happens because these conditions can cause greater muscular activity at rest, which results in an increase in the intramuscular pressure and, consequently, greater mechanical compression of the blood vessels of the muscles in the region affected; over time, the reduced blood supply leads to a reduction in skin temperature(36-37).

Nevertheless, specifically in the case of chronic pain in the spinal column, no evidence available was found in the literature reporting possible clinical effects of EA on skin temperature, meaning that the present results were pioneering in the investigation of this phenomenon.

$E A$, therefore, is a therapeutic resource that is easy to apply, low in cost and with a relative absence of side effects, which assists in reestablishing health as a whole(29). In addition to this, it may be applied, multi-professionally, at all levels of healthcare. In this scenario, upon evidencing the high prevalence of people with chronic back pain ${ }^{(1)}$ and the negative impacts that this causes on their lives ${ }^{(2-4)}$ EA may be seen as an intervention tool which may be easily implemented in the nurse's clinical practice, so as to help these people's rehabilitation and, consequently, improve the quality of their lives.

As possible limitations of this study, one may consider the withdrawal of some volunteers from the treatment and placebo groups due to the discomfort caused by the insertion and placement of the semipermanent needles in the ear. It is believed, furthermore, that the fact that the volunteers from the control group remained for a considerable period of time receiving only the assessments may have caused a greater loss in this group, although they were assured that they had the right to receive the intervention at the end of the follow-up period. Furthermore, the intervention was undertaken individually, as is strongly recommended by TCM, and this hinders the use of the same auricular points, although satisfactory and statistically significant results have been obtained in this way.

Further studies are suggested, in different contexts, to improve the substantiation of these results, as well as investigating the action of EA on other behavioral and physiological variables of chronic pain related to the musculoskeletal system.

\section{Conclusion}

There was a statistically significant difference between the groups and over time, in relation to physical disability; and in relation to tissue temperature, this difference occurred during the follow-up time. These findings demonstrate that EA is an intervention that may be implemented in the nurse's clinical practice, so as to assist the treatment and, consequently, the rehabilitation of people with chronic pain in the spinal column. It is hoped that the results of this study will encourage the use of this therapeutic resource by nurses in their care activities.

\section{References}

1. Maher C, Underwood M, Buchbinder R. Non-specific low back pain. Lancet. [Internet]. 2017 [cited Jun 2 2017];389(10070):736-47. Available from: https:// www.thelancet.com/journals/lancet/article/PIIS01406736(16)30970-9/fulltext

2. Salaffi F, Ciapetti A, Carotti, M. Pain assessment strategies in patients with musculoskeletal conditions. Reumatismo. [Internet]. 2012 [cited Aug 17 2016];64(4):216-29. Available from: https://pdfs. semanticscholar.org/e3b4/8847e2590ae5cc35a2eb1b43 5d269ef5037b.pdf

3. Eggermont LH, Leveille SG, Shi L, Kiely DK, Shmerling $\mathrm{RH}$, Jones RN, et al. Pain Characteristics Associated With the Onset of Disability in Older Adults: The MOBILIZE Boston Study. J Am Geriatr Soc. [Internet]. 2014 [cited Mar 1 2016];62(6):1007-16. Available from: https:// www.ncbi.nlm.nih.gov/pmc/articles/PMC4057984/pdf/ nihms574559.pdf

4. Salazar A, Dueñas M, Mico JA, Ojeda B, AgüeraOrtiz L, Cervilla JA, et al. Undiagnosed mood disorders and sleep disturbances in primary care patients with chronic musculoskeletal pain. Pain Med. [Internet]. 2013 [cited Feb 20 2017];14(9):1416-25. Available from: https://academic.oup.com/painmedicine/ article/14/9/1416/1879241 
5. Roland M, Morris R. A study of the natural his $\neg$ tory of back pain. Part I: development of a reliable and sensitive measure of disability in low-back pain. Spine. [Internet]. 1983 [cited Nov 13 2015];8:141-4. Available from: https://journals.Iww.com/spinejournal/ Abstract/1983/03000/A_Study_of_the_Natural_History_ of_Back_Pain_Part.4.aspx

6. Sardá Júnior JJ, Nicholas MK, Pimenta CAM, Asghari A, Thieme AL. Validação do Questionário de Incapacidade Roland Morris para dor em geral. Rev. Dor. [Internet]. 2010 [Acesso 25 jun 2017];11(1):28-36. Disponível em: http://files.bvs.br/upload/S/1806-0013/2010/v11n1/ a1496.pdf

7. Dibai-Filho AV, Guirro RR. Evaluation of myofascial trigger points using infrared thermography: a critical review of the literature. J Manipulative Physiol Ther. [Internet]. 2015 [cited Jun 13 2017];38(1):86-92. Available from: http://www.jmptonline.org/article/ S0161-4754(14)00213-9/fulltext

8. Bicego KC, Barros RC, Branco LG. Physiology of temperature regulation: comparative aspects. Comp Biochem Physiol A Mol Integr Physiol. [Internet]. 2007 [cited Jun 21 2017];147(3):616-39. Available from: https://www.sciencedirect.com/science/article/pii/ S1095643306003047

9. Magalhães MF, Dibai-Filho AV, de Oliveira Guirro EC, Girasol CE, de Oliveira AK, Dias FRC, et al. Evolution of Skin Temperature after the Application of Compressive Forces on Tendon, Muscle and Myofascial Trigger Point. PLoS ONE. [Internet]. 2015 [cited Jun 25 2017];10(6): e0129034. Available from: http:// journals.plos.org/plosone/article/file?id=10.1371/ journal. pone.0129034\&type $=$ printable

10. Ruela, LO, Moura, CC, Gradim, CVC, Stefanello, J, Iunes, DH, Prado, RR. Implementação, acesso e uso das práticas integrativas e complementares no sistema único de saúde: Revisão da literatura. Cien Saúde Coletiva. [Internet]. 2018 [Acesso 27 maio 2018]. Disponível em: http://www.cienciaesaudecoletiva.com.br/artigos/ implementacao-acesso-e-uso-das-praticas-integrativase-complementares-no-sistema-unico-de-saude-revisaoda-literatura $/ 16793$ ? id $=16793$ \&id $=16793$

11. Lee EJ, Frazier SK. The efficacy of acupressure for symptom management: a systematic review. J Pain Symptom Manage. [Internet]. 2011 [cited Aug 17 2017];42(4):589-603. Available from: https:// www.ncbi.nlm.nih.gov/pmc/articles/PMC3154967/pdf/ nihms282571.pdf

12. Zhao HJ, Tan JY, Wang T, Jin L. Auricular therapy for chronic pain management in adults: A synthesis of evidence. Complement Ther Clin Pract. [Internet]. 2015 [cited Aug 17 2017];21(2):68-78. Available from: https://www.sciencedirect.com/science/article/pii/ S1744388115000286?via\%3Dihub

13. Krauss, A. Why all randomised controlled trials produce biased results. Annals Medicine. [Internet]. 2018 [cited May 21 2018];50(4):312-22. Available from: https://www.tandfonline.com/doi/pdf/10.1080/078538 90.2018.1453233? needAccess=true

14. Task Force on Taxonomy of the International Association for the Study of Pain. Classification of chronic pain. Descriptions of chronic pain syndromes and definitions of pain terms. 2nd ed. Pain Suppl. [Internet]. 1986 [cited May 30 2017];3:S1-226. Available from: https://s3.amazonaws.com/rdcms-iasp/files/production/ public/Content/ContentFolders/Publications2/FreeBooks/ Classification-of-Chronic-Pain.pdf

15. Yeh CH, Kwai-Ping Suen L, Chien LC, Margolis L, Liang Z, Glick RM, et al. Day-to-Day Changes of Auricular Point Acupressure to Manage Chronic Low Back Pain: A 29day Randomized Controlled Study. Pain Med. [Internet]. 2015 [cited May 30 2017];16(10):1857-69. Available from: https://academic.oup.com/painmedicine/ article/16/10/1857/2460235

16. Miot HA. Tamanho da amostra em estudos clínicos e experimentais. ] Vasc Bras. [Internet]. 2011 [cited May 30 2017];10:275-8. Available from: http://www.scielo. $\mathrm{br} / \mathrm{pdf} / \mathrm{jvb} / \mathrm{v} 10 \mathrm{n} 4 / \mathrm{v} 10 \mathrm{n} 4 \mathrm{a} 01$

17. Nusbaum L, Natour J, Ferraz MB, Goldenberg J. Translation, adaptation and validation of the RolandMorris questionnaire - Brazil Roland-Morris. Braz J Med Biol Res. [Internet]. 2001 [cited May 2 2015];34:203-10. Available from: http://www.scielo.br/pdf/bjmbr/ v34n2/3922m.pdf

18. Brioschi ML, Yeng LT, Pastor EMH, Colman D, Silva FMRM, Teixeira MJ. Documentação da síndrome dolorosa miofascial por imagem infravermelha. Acta Fisiatr. [Internet]. 2007 [cited May 30 2017];14(1):41-8. Available from: http://www.revistas.usp.br/ actafisiatrica/article/view/102775/101061

19. Moura CC, Iunes DH, Agostinho AAM, Santos N, Silva AM, Chaves ECL. Assessment and correlation between subjective and physiological variables of chronic spinal pain. Rev Dor. [Internet]. 2017 [cited May 30 2017];18:1-5. Available from: http://www.scielo.br/pdf/ rdor/v18n3/1806-0013-rdor-18-03-0194.pdf

20. MacPherson $H$, Altman DG, Hammerschlag R, Youping L, Taixiang W, White A, et al. Revised Standards for Reporting Interventions in Clinical Trials of Acupuncture (STRICTA): Extending the CONSORT Statement. Plos Medicine. [Internet]. 2010 [cited Apr 25 2015];7(6):1-11. Available from: https://www.ncbi.nlm.nih.gov/pmc/ articles/PMC2882429/pdf/pmed.1000261.pdf

21. World Federation of Acupuncture-Moxibustion Societies (WFAS). Auricular Acupuncture Point (WFAS 
STANDARD-002: 2012). WId J Acupunct Moxibustion. [Internet]. 2013 [cited Apr 25 2015];23(3):12-21. Available from: https://www.sciencedirect.com/science/ article/pii/S1003525713600549

22. Alexander LK, Lopes B, Ricchetti-Masterson K, Yeatts KB. Randomized Controlled Trials (Experimental Studies). 2th ed. UNC CH Department of Epidemiology [Internet]; 2015 [cited May 22 2018]. p. 1-5. Available from: https://sph.unc.edu/files/2015/07/nciph_ ERIC10.pdf

23. Vos T, Barber RM, Bell B, Bertozzi-Villa A, Biryukov S, Bolliger I, et al. Global, regional, and national incidence, prevalence, and years lived with disability for 301 acute and chronic diseases and injuries in 188 countries, 19902013: a systematic analysis for the Global Burden of Disease Study 2013. Lancet. [Internet]. 2015 [cited May 23 2018];386(9995):743-800. Available from: http:// www.thelancet.com/pdfs/journals/lancet/PIIS01406736(15)60692-4.pdf

24. Hoy D, March L, Brooks P, Blyth F, Woolf A, Bain C, et al. The global burden of low back pain: estimates from the Global Burden of Disease 2010 study. Annals Rheum Dis. [Internet]. 2014 [cited May 23 2018];73(6):96874. Available from: https://ard.bmj.com/content/ annrheumdis/73/6/968.full.pdf

25. Duenas M, Ojeda B, Salazar A, Mico JÁ, Failde I. $A$ review of chronic pain impact on patients, their social environment and the health care system. J Pain Res. [Internet]. 2016 [cited May 27 2018];9:457-67. Available from: https://www.ncbi.nlm.nih.gov/pmc/ articles/PMC4935027/pdf/jpr-9-457.pdf

26. Jordan K, Dunn KM, Lewis M, Croft P. A minimal clinically important difference was derived for the Roland-Morris Disability Questionnaire for low back pain. J Clin Epidemiol. [Internet]. 2006 [cited Feb 16 2016];59(1):45-52. Available from: https://www.sciencedirect.com/science/article/pii/ S0895435605002623

27. Yeh CH, Morone NE, Chien LC, Cao Y, Lu H, Shen J, et al. Auricular point acupressure to manage chronic low back pain in older adults: a randomizedcontrolled pilot study. Evid Based Complement Alternat Med. [Internet]. 2014 [cited May 27 2018];2014:1-11. Available from: https://www.ncbi.nlm.nih.gov/pmc/articles/ PMC4134789/pdf/ECAM2014-375173.pdf

28. Yeh $\mathrm{CH}$, Chien LC, Balaban D, Sponberg R, Primavera J, Morone $\mathrm{NE}$, et al. A randomized clinical trial of auricular point acupressure for chronic low back pain: a feasibility study. Evid Based Complement Alternat Med. [Internet]. 2013 [cited May 27 2018];2013:1-9. Available from: https:// www.ncbi.nlm.nih.gov/pmc/articles/PMC3603381/pdf/ ECAM2013-196978.pdf
29. Kurebayashi LFS, Silva MJP. Chinese auriculotherapy to improve quality of life of nursing team. Rev Bras Enferm. [Internet]. 2015 [cited May 22 2018];68(1):109-15. Available from: http://www.scielo.br/pdf/reben/v68n1/ en_0034-7167-reben-68-01-0117.pdf

30. Miller LR, Miller FG. Understanding placebo effects: Implications for nursing practice. Nurs Outlook. [Internet]. 2015 [cited May 23 2018];63(5):601-6. Available from: https://www.nursingoutlook.org/article/ S0029-6554(15)00120-7/pdf

31. Reis F, Guimarães F, Nogueira LC, Meziat-Filho N, Sanchez TA, Wideman T. Association between pain drawing and psychological factors in musculoskeletal chronic pain: A systematic review. Physiother Theory Pract. [Internet]. 2018 [cited May 23 2018]:1-10. Available from: https://www.tandfonline.com/doi/full/10.1080/0959398 5.2018.1455122?scroll=top\&needAccess =true

32. Gerhart JI, Burns JW, Bruehl S, Smith DA, Post KM, Porter LS, et al. Variability in negative emotions among individuals with chronic low back pain: relationships with pain and function. Pain. [Internet]. 2018 [cited May 23 2018];159(2):342-50. Avaiable from: https://insights. ovid.com/pubmed?pmid $=29140926$

33. Barão VAR, Gallo AKG, Zuim PRJ, Garcia AR, Assunção WG. Effect of occlusal splint treatment on the temperature of different muscles in patients with TMD. J Prosthodont Res. [Internet]. 2011 [cited May 24 2018];55:19-23. Available from: https://www.sciencedirect.com/science/article/pii/ S1883195810000848?via\%3Dihub

34. Silva NCM, Castro HA, Carvalho LC, Chaves $\mathrm{ECL}$, Ruela LO, Iunes DH. Reliability of Infrared Thermography Images in the Analysis of the Plantar Surface Temperature in Diabetes Mellitus. J Chiropr Med. [Internet]. 2018 [cited May 24 2018];17(1):30-5. Available from: https://www.journalchiromed.com/ article/S1556-3707(16)30158-4/pdf

35. Holey LA, Dixon J, Selfe J. An exploratory thermographic investigation of the effects of connective tissue massage on autonomic function. J Manip Physiol Ther. [Internet]. 2011 [cited May 24 2018];34(7):45762. Available from: https://www.jmptonline.org/article/ S0161-4754(11)00120-5/fulltext

36. Rodrigues-Bigaton D, Dibai-Filho AV, Packer AC, Costa AC, de Castro EM. Accuracy of two forms of infrared image analysis of the masticatory muscles in the diagnosis of myogenous temporomandibular disorder. J Bodyw Mov Ther. [Internet]. 2014 [cited May 24 2018];18(1):49-55. Available from: https:// www.bodyworkmovementtherapies.com/article/S13608592(13)00072-7/pdf

37. Girasol CE, Dibai-Filho AV, Oliveira AK, Jesus Guirro RR. Correlation Between Skin Temperature Over 
Myofascial Trigger Points in the Upper Trapezius Muscle and Range of Motion, Electromyographic Activity, and Pain in Chronic Neck Pain Patients. J Manipulative Physiol Ther. [Internet]. 2018 [cited May 27 2018];41(4):350-7. Available from: https://www.jmptonline.org/article/ S0161-4754(16)30311-6/pdf

Corresponding Author:

Caroline de Castro Moura

Universidade Federal de Minas Gerais. Escola de Enfermagem

Av. Professor Alfredo Balena, $\mathrm{s} / \mathrm{n}$

Bairro: Santa Efigênia

CEP: 30130-100, Belo Horizonte, MG, Brasil.

E-mail: carol_castro_m@hotmail.com
Copyright $\odot 2018$ Revista Latino-Americana de Enfermagem This is an Open Access article distributed under the terms of the Creative Commons (CC BY).

This license lets others distribute, remix, tweak, and build upon your work, even commercially, as long as they credit you for the original creation. This is the most accommodating of licenses offered. Recommended for maximum dissemination and use of licensed materials. 